\title{
"Veracht ons Hollandt niet, wy hebben schooen Koeyen, Daer uyt dat soete-melck, en room, en boter vloeyen...". De oude Nederlanden weerspiegeld op de blauwe tegels in Krzyżowice
}

\begin{abstract}
The purpose of this paper is to show a collection of Dutch azure tiles stored in an old palace in Krzyżowice (Lower Silesia, Poland). The article presents a brief history of the palace and shows the images applied to decorate the tiles, focusing mainly on the image of a Dutch village: landscapes with bridges, mills, boats, scenic pieces presenting fishermen at work, people skating, animals (especially cows). The text is to show the way in which the tile images and other products of Dutch culture relate to one another (copperplate engravings, poetry). The paper thus seeks to present what makes this collection of tiles interesting in this particular part of Europe.
\end{abstract}

Keywords: Silesia, Krzyżowice, Dutch tiles, image, Dutch village.

In het Silezische ${ }^{1}$ dorpje Krzyżowice-Wierzbice (Duits: Kreiselwitz/KieferbergSchlanz) $)^{2}$ bevindt zich een oud paleis waar vanaf de achttiende eeuw tot de jaren dertig van de twintigste eeuw de welgestelde en invloedrijke adellijke families Von Reichell en $\mathrm{Zu}$ Eulenburg resideerden. Tegenwoordig wordt het gebouw voor

1 Silezië (Pools: Śląsk, Duits: Schlesien), een historische regio in Midden-Europa, strekt zich in de midden- en bovenloop van de Oder uit. Vanaf de tiende eeuw tot het begin van de veertiende eeuw hoorde het bij het toenmalige Koninkrijk Polen. In de volgende eeuwen werd Silezië bemachtigd door de Habsburgse dynastie, het Pruisische huis Hohenzollern en het Duitse Keizerrijk (het Tweede Duitse Rijk). Pas vanaf het einde van de Tweede Wereldoorlog in 1945 maakt Silezië weer grotendeels deel uit van Polen. Het dorpje Krzyżowice ligt in Neder-Silezië, het noordwestelijke deel van de regio gesitueerd in de middenloop van de Oder.

2 Poolse en Duitse aardrijkskundige namen zijn verbonden met de ingewikkelde geschiedenis van deze regio, die in het verleden onder Pools en Duits gezag stond. 
andere doeleinden gebruikt: het functioneert als gemeentelijke school (Powiatowy Zespót Szkót nr 1). Tot op heden kunnen wij daar wit-blauwe, Nederlandse tegels bewonderen.

De aanwezigheid van tegelcollecties in Silezië was niet bijzonder. De muren van veel adellijke paleizen en burgerlijke residenties werden vanaf de zeventiende tot het begin van de negentiende eeuw bedekt met wit-blauwe tegels, vervaardigd in Harlingen, Utrecht, Rotterdam, Amsterdam, Makkum en Bolsward (Oczko \& Pluis 2018: 204-211). Dat had an de ene kant heel praktische redenen: dankzij de tegels werden de donkere ruimtes en gangen lichter, bovendien konden ze makkelijker worden schoongemaakt (Szmida-Półbratek 2010: 13-14). Aan de andere kant was hun rol vooral decoratief. In de negentiende eeuw ging dat nog gepaard met de mode in de Europese toegepaste keramiek (ook aanwezig in Neder-Silezië) om voornamelijk keukenvoorwerpen in wit-blauw te vervaardigen en met stereotiepe Hollandse motieven, zoals tulpen, molens, boten, of bruggetjes te versieren. Dit verschijnsel wordt door Piotr Oczko in zijn monografie Miotta i Krzyż. Kultura sprzatania $w$ dawnej Holandii, albo historia pewnej obsesji $i^{3}$ gekarakteriseerd als "een echte obsessie" verwezenlijkt door een Duitse keramiekfabriek - Wächtersbach in Hessen - die zich in de productie van blauw porselein naar het Delftse voorbeeld specialiseerde (Oczko 2013: 597-598).

In dit artikel zal worden geanalyseerd welk beeld van het Nederlandse dorpsleven door de oude Nederlandse aardewerkbedrijven voor hun buitenlandse, in dit geval Silezische, klanten werd gecreëerd. Welke alledaagse motieven waren er in de tegelcollectie van dit paleis aanwezig en welke niet? Mijn vraagstelling is ook: in hoeverre zijn de tegels uit het Silezische paleis een afspiegeling van de Nederlandse cultuur, d.w.z. welke wederzijdse relaties bestonden er tussen deze tegels en andere verschijnselen van de oude Nederlandse cultuur (poëzie, prenten, etsen, gravures)?

\section{Tegelcollecties in Silezië}

De volledige geschiedenis van de collecties Nederlandse tegels in Silezië werd nog niet gereconstrueerd en eist een grondig onderzoek. De decoratieve mode om paleizen of residenties met tegels te versieren was waarschijnlijk beïnvloed door een gelijke trend in Oost-Tsjechië, Moravië of Beieren en tegels werden geleverd via Hamburg en Keulen, in tegenstelling tot andere regio's van het tegenwoordige Polen (het zgn. Koninklijk Pruisen en het Pools-Litouwse Gemenebest), waar ze via havens in Gdańsk of Elbląg aangevoerd werden (Oczko \& Pluis 2018: 203).

${ }^{3}$ In 2020 verscheen de Nederlandse editie met de titel Bezem \& Kruis. De Hollandse schoonmaakcultuur of de geschiedenis van een obsessie in vertaling van Paul Hulsenboom (Leiden: Primavera Pers). 
Momenteel is het nog moeilijk om definitief te bepalen in hoeverre de toestroom van tegels naar dit gebied het gevolg was van eeuwenoude contacten tussen Silezië en de Nederlanden; contacten van economische (handelsrelaties vanaf de tijd van de Hanze), culturele (Nederlandse invloeden in de Silezische schilderkunst, beeldhouwkunst of sacrale en seculiere architectuur), academische en wetenschappelijke (Sileziërs aan Noord-Nederlandse universiteiten in de zeventiende eeuw) aard. ${ }^{4}$ Er bestond een belangstelling voor de Nederlandse cultuur die voortkwam uit die lange relaties, maar het onderzoek naar deze problematiek is nog niet afgerond.

De collectie in Krzyżowice was niet de enige in Neder-Silezië. Jammer genoeg zijn er van al die verzamelingen van Nederlandse tegels tot op heden slechts enkele overgebleven. ${ }^{5}$ Eén daarvan bevindt zich in het paleis Pakoszów (Duits: Wernersdorf) dat in 1725 door Johann Martin Gottfried werd gekocht. Gottfried was een rijke koopman die zich met de productie en handel van linnen bezighield. De laatste eigenaars van het paleis in Pakoszów waren Georg Friedrich Smith (1703-1757) en tussen 1771 en 1945 de familie Hess (Perzyński 2012: 100). Na de Tweede Wereldoorlog werd het paleis door de Poolse staat overgenomen en vervulde het verschillende functies, o.m. die van een weeshuis. Later werden er ook sociale woningen ingericht, net als een autogarage en een schietbaan. Vandaag behoort het toe aan Ingrid en Hagen Hartmann, erfgenamen van de laatste eigenares en functioneert het als luxehotel (Perzyński 2012: 86-101). Wit-blauwe achttiende-eeuwse tegels uit Amsterdam (ong. 1740-1760) bedekken de muren van een ruimte in een klein gebouw achter het hoofdgebouw van het paleis (Oczko \& Pluis 2018: 210) en stellen vooral alledaagse, maritieme, pastorale, en bijbelse scènes voor.

Bovendien bevinden zich Nederlandse tegels in de zgn. Kamer van Beyersdorf van het voormalige Koninklijk Paleis te Wrocław (vandaag het Stedelijk Museum - Muzeum Miejskie Wrocławia). Oorspronkelijk werden ze gekocht door de zeventiende-eeuwse lakenkoopman Adrian Bögel voor zijn huis op de Zoutmarkt (Plac Solny). Hij liet ze waarschijnlijk uit Hamburg (of eventueel Gdańsk) invoeren en bedekte er een van de drie ruimtes op de derde verdieping mee (Szmida-Półbratek 2010: 13). In het midden van de negentiende eeuw werd

${ }^{4}$ Over contacten tussen Silezië en de Nederlanden bestaat een significante literatuur, waaronder veel artikelen en monografieën van Stefan Kiedroń (o.m. Ślask-Niderlandy: Złoty wiek 1550 1650, Wrocław 1998; Cultural Ties between Silesia and the Low Countries in the Golden Age, Olomouc 2003) of de gezamenlijke publicatie Niderlandyzm na Ślasku i w krajach ościennych onder redactie van M. Kapustka, A. Kozieł en P. Oszczanowski (Wrocław 2003) e.a.

5 Tot de belangrijkste publicaties over dit onderwerp behoren o.m. het boek van P. Oczko en J. Pluis: Holenderskie flizy na dawnych ziemiach polskich i ościennych. 2. Mody i wnętrza (Malbork 2018) of het werk van M. Szmida-Półbratek: Świat zaklęty w błękicie. Pokój Beyersdorfów w Pałacu Królewskim we Wrocławiu. Die in azur verzauberte Welt. Beyersdorf-zimmer im Königsschloss in Breslau (Wrocław 2010). 
het huis door de familie Beyersdorf gekocht, die de collectie tegels in 1898 aan Schlesisches Museum für Kunstgewerbe und Altertümer schonk (Szmida-Półbratek 2010: 14-15). Vanaf 1940 behoort ze tot het Stedelijk Museum van Wrocław. Deze verzameling tegels en de collectie in Pakoszów vertonen een duidelijke gelijkenis en men vermoedt dat ze elkaars ontstaan inspireerden (Szmida-Półbratek 2010: 14). Ook hier kunnen we dus idyllische en bijbelse taferelen bewonderen, net als beelden van de zee, havens, schepen en boten.

Er zijn nog twee oude paleizen in Silezië waar men Nederlandse tegels kan vinden. Ze bevinden zich in Siedlimowice (met als voormalige eigenaars de familie Von Korn, beroemde uitgevers uit Breslau) en in Większyce (het paleis van Marc Heymann, die uit een rijke bankiersfamilie uit Breslau kwam). Beide collecties ontstonden aan het einde van de negentiende eeuw en werden vervaardigd in Harlingen door Jan van Hulst (Oczko \& Pluis 2018: 211-212). Het oude paleis in Siedlimowice is helaas in verval geraakt en daar zijn alleen enkele Nederlandse decoratieve tegels overgebleven. Het gebouw in Większyce heeft meer geluk gehad: het functioneert tegenwoordig als restaurant en aan de muren van de keuken kunnen bezoekers gerenoveerde tegels met Nederlandse landschappen bewonderen (Oczko \& Pluis 2018: 211-212).

\section{Geschiedenis van het paleis in Krzyżowice en herkomst van de tegelcollectie}

Het paleis in Krzyżowice werd gebouwd in de achttiende eeuw. Daarna werd het drie keer verbouwd: eerst in 1793, verder in 1854 en 1891 na een brand (Perzyński 2012: 320). Vanaf het ontstaan tot de eerste jaren van de twintigste eeuw functioneerde het als zetel van de baronnen Von Reichell en daarna behoorde tot het einde van de Tweede Wereldoorlog toe aan de graven Zu Eulenburg (Perzyński 2012: 319). De dochter van Carl Wilhelm Reichell (de laatste mannelijke nakomeling van deze familie en paleiseigenaar) trouwde met Carl Conrad von Tschirsky, maar haar zoon Carl Benno nam (volgens de wens van zijn moeder) de achternaam en het wapen van de familie Reichell over (Gajda 2007: 22). Vanaf het begin van de twintigste eeuw tot en met januari 1945 beheerde Euphemia Reichell (de dochter van Carl Benno en de vrouw van graaf $\mathrm{Zu}$ Eulenburg) de goederen in Krzyżowice. In februari 1945 vluchtte zij voor het naderende Sovjetleger, maar kwam later terug om voor haar eigendommen te zorgen (Perzyński 2012: 312). Waarschijnlijk om deze reden werd het paleis nauwelijks beschadigd tijdens de gevechten en doorstond het deze moeilijke periode in redelijk goede staat (Gajda 2007: 22). Een dergelijke situatie was toen niet gewoon: de meeste paleizen, aristocratische of patricische residenties in de regio werden verwoest of 
leeggeroofd door Sovjetmilitairen ${ }^{6}$ of later door de Poolse naoorlogse, communistische regering die vaak tussen de jaren 1949-1989 zgn. 'PGR's' (Państwowe Gospodarstwa Rolne - 'staatslandbouwbedrijven') in deze goederen vestigde. Soms werden oude gebouwen verdeeld in sociale woningen als onderdak voor de armsten (Perzyński 2012: 101). Om ideologische redenen verzuimde de nieuwe communistische regering ervoor te zorgen dat die architectonische schatten (beschouwd als Duitse d.i. nazi-eigendommen) in de vooroorlogse staat behouden bleven. Het voormalige paleis te Krzyżowice was dus een uitzondering in dit opzicht. In 1946 werd daar de Faculteit Landbouw van de Universiteit Wrocław (Wydziat Rolny Uniwersytetu Wroctawskiego) gevestigd en in 1947 twee scholen: het Staatsgymnasium en het Landbouwlyceum (Państwowe Gimnazjum i Liceum Rolnicze), die een jaar later tot het Staatslandbouwlyceum (Państwowe Liceum Rolnicze) werden verenigd (Gajda 2007: 37). Het hoofdgebouw van het paleis werd gerenoveerd in de jaren vijftig, zeventig en tachtig van de twintigste eeuw, maar er staan nog enkele werkzaamheden te wachten vooraleer het terug in zijn originele staat is.

Vanaf het einde van de negentiende eeuw tot en met de jaren veertig van de twintigste eeuw behoorde het landgoed Krzyżowice tot de grootste en rijkste goederen in Neder-Silezië. ${ }^{8}$ Het paleis was beroemd om de rijk ingerichte kamers, ruime Franse en Engelse tuinen met een zonnewijzer en standbeelden van de overledenen van de familie von Reichell, alsook om het uitgestrekte bouwland en de levende have (vooral koeien en paarden) (Gajda 2007: 22-23). Op de eerste verdieping van het paleis bevonden zich o.m. slaapkamers, een omkleedkamer, kleine eetkamers, een badkamer, een kinderkamer met een slaapkamer voor de au pair en een kleine bibliotheek. De begane grond werd voorzien van o.m. woonkamers van de ouders van graaf Mortimer zu Eulenburg, hun slaapkamer, de tweede badkamer, gastkamers en verschillende dienstkamers. Er waren ook ruimtes rijk versierd met wit-blauwe Nederlandse tegels: de gang, de woonkamer en de keuken van Luise von Tschirsky met een ruime eetkamer ingericht in Hollandse stijl met een verzameling vazen, kannen en schotels van Delfts aardewerk. Deze collectie van snuisterijen bestaat niet meer. Er is alleen een open haard met een spiegel overgebleven, die ook door Nederlandse tegels wordt omringd

${ }^{6}$ Vanaf het begin van 1945 vonden er hevige en bloedige gevechten in Neder-Silezië plaats tussen het Rode Leger en de Wehrmacht. Het leger van de Sovjet-Unie bezette bijna het gehele gebied behalve de stad Wrocław (Breslau) die zich als Festung Breslau verdedigde tot zijn capitulatie op 6 mei 1945. Tijdens de gevechten werd de regio ernstig verwoest, wat grote invloed had op de economische situatie na de oorlog (Wrzesiński 2009: 625).

7 Deze boerenbedrijven behoorden tot de staat en de akkers werden daar door de zgn. 'boer-arbeiders' (Pools: chtopo-robotnicy) verbouwd, die de staat ter plekke onderdak verleende.

8 De school beschikt over enkele documenten en foto's die in 2007 door graaf Mortimer zu Eulenburg (de laatste levende afstammeling van deze familie, geb. 1936) zijn verstrekt, en die deze bewering bevestigen (Gajda 2007: 22-31; Perzyński 2012: 307-312). 
(Gajda 2007: 21-22; Perzyński 2012: 320). De verzameling tegels in de voormalige eetkamer werd vervaardigd in Amsterdam, in de periode 1740-1750, en in Makkum rond 1750. Volgens Oczko "is dit tot nu toe het enige bewijs van het gebruik van Makkum-producten in dit deel van Europa" (2018: 206). De andere tegels ontstonden later, namelijk rond 1900 in Harlingen (Oczko \& Pluis 2018: 206). De tegels in de gang werden vervaardigd in Utrecht en Amsterdam in de jaren 1740-1750 (Oczko \& Pluis 2018: 204). Ze zijn allemaal handgemaakt: op een witte achtergrond werden verschillende taferelen in blauw afgebeeld. Onder hoekmotieven onderscheidt zich op de eerste plaats de zgn. ossenkop. Dit populaire hoekmotief was in gebruik vanaf het midden van de zeventiende eeuw (met een uitzondering: de gekleurde variant kwam ook voor in de eerste helft van dit tijdperk) tot en met de negentiende eeuw. Het werd waarschijnlijk afgeleid van een ander hoekmotief de Bourgondische lelie (Korf 1979: 42-43, 45, 47). In geval van groepen tegels met een landschap afgebeeld in de zgn. dubbel gebogen achtkant werd het andere hoekmotief gebruikt, namelijk de kwartrozet (Pluis 2013: 151; Oczko \& Pluis 2018: 206).

Helaas beschikken we tegenwoordig slechts over een beperkt aantal documenten van het gebouw zelf en daarom bestaan er geen volledige gegevens over de lotgevallen van de collectie tegels in dit oude paleis.

\section{Het beeld van de oude Nederlanden in de tegelcollectie van Krzyżowice}

De motieven van de tegels in Krzyżowice creëren een stereotyperend beeld van de leefwijze in de oude Nederlanden, met name op het Nederlandse platteland. Dit beeld is gebaseerd op een aantal elementen die kenmerkend (hoewel niet altijd uniek) zijn voor de Nederlandse omgeving. Er worden dus watergebieden afgebeeld met boten en schepen en alledaagse activiteiten zoals vissen. De visserij en met name de haringvangst was een belangrijke sector van de Nederlandse economie (Van Deursen 2010: 34-36). Bovendien toont men akkers, weiden, het hoeden van dieren en de jacht. Op tegels lieten de makers verder elementen zoals beweegbare bruggen of wind- en watermolens zien. Er worden verschillende diersoorten voorgesteld: vogels, insecten, hazen, vissen, schapen, paarden en koeien. Alle bovenvermelde motieven functioneerden ook in andere Nederlandse cultuuruitingen zoals de schilderkunst of literatuur. Uiteraard kwamen ze ook voor in cultuurverschijnselen van andere landen. Echter, er wordt in dit artikel niet beweerd dat ze uitsluitend de Nederlandse realiteit en cultuur karakteriseerden. De aanwezigheid van de vermelde taferelen van watergebieden, boten, vissen e.a. op Nederlandse tegels toont hoe nauw de inwoners met het water samenleefden, 
het belang ervan in het dagelijks leven en het helpt (samen met de pastorale scènes uitgebeeld op de tegels) het beeld van het 'idyllische' Nederland te scheppen.

Het beeld van het leven op het rustige Nederlandse platteland creëerden ook dichters in hun poëzie uit de zeventiende en achttiende eeuw. De verheerlijking van het dorpsleven kwam voort uit twee literaire antieke tradities: De Epoden van Horatius (lofzang op het eenvoudige boerenleven) en Vergilius' Georgica (waardering voor het leven op een buitenplaats) (Gelderblom 1994: 131). Verwijzend naar Horatius' tweede epode Beatus ille (Gelukkig is hij) schreven Nederlandse dichters over het leven en werk van gewone boeren. Ze toonden hun werkzaamheden in de omgeving van een prachtige natuur, en beeldden de overheersende vrede, rust, veiligheid en het familiegeluk af (Gelderblom 1994: 131-132). De auteurs creëerden dus een geïdealiseerd beeld van het Nederlandse platteland waar het werk niet zwaar is, maar een onscheidbaar onderdeel van het leven vormt en waar de oogst later de wintermaanden helpt doorstaan. Mensen leven volgens de principes van de natuur in dit aardse, 'Hollandse paradijs'. Aansluitend bij Georgica van Vergilius en geïnspireerd door andere klassieke, Neolatijnse, Italiaanse en Franse werken die W.B. de Vries met de term 'buitenlevenliteratuur' definieert, ontstonden de zgn. hofdichten (1998: 17). De auteurs presenteerden daarin een visie van het vrije en rustige leven buiten de stad, overeenkomstig de jaargetijden, waar men veilig en zorgeloos van de vruchten van de natuur en van de literatuur (bijv. Bijbelstudie) kan genieten. Nederlandse hofdichten verwezen naar de gewoonte in de Republiek van vooral rijke burgers (kooplieden, ambtenaars) om als gepensioneerden in hun buitenhuizen te gaan wonen en bewezen ook de waarde van dit leven (De Vries 1998: 20-21). De beschrijvingen van de omgeving in dit genre dienen echter verschillende doeleinden. Aan de ene kant maakt de lezer kennis met de topografie van een bepaalde landstreek, maar aan de andere kant krijgt hij morele lessen gebaseerd op de Bijbel of mythologie en verborgen in het beeld van de natuur (Gelderblom 1994: 132). De functie van dit soort weergaven van het land en de omgeving was dus ook didactisch. Veel dichters, zoals Cats, Westerbaen of Huygens lieten de natuur zien als manifestatie van God op aarde (Kuiper 2015: 30). De bedoeling van de Nederlandse dichters was om in hun hofdichten de ideologie van het buitenleven te combineren met een (vaak geïdealiseerde) beschrijving van een bepaald buitenhuis, zijn omgeving en het leven van zijn bewoners (De Vries 1998: 42).

In geval van de beeldende kunst uit dezelfde periodes is het niet altijd mogelijk om die uitsluitend te associëren met de term 'realisme' in de betekenis van "het op nauwkeurige en betrouwbare wijze zonder bijbedoelingen weergeven van het geziene" (Sluijter 1990: 5). Er ontstonden uiteraard kunstwerken die de inheemse, idyllische omgeving realistisch weergaven, maar volgens Ziemba speelden Nederlandse schilders daarnaast met verschillende conventies in hun 
werken: schilderen 'naar het leven', illusie en fantasie (239). Hij verwijst ook naar het artikel van Simon Schama Dutch Landscapes: Culture as Foreground (1987) waarin de auteur beweert dat 'portretten' van Nederland (landschappen met of zonder dieren en mensen, zee- of stadsgezichten e.a.) het gezag van de Republiek der Verenigde Nederlanden en haar maatschappij over het grondgebied weergaven en de zgn. patriotic geography representeerden (Ziemba 2005: 324). Maar Nederlandse schilders speelden ook met het publieke geheugen (Ziemba 2005: 339-340). Op basis van tekeningen (vaak buiten gemaakt) en met behulp van hun eigen verbeelding combineerden ze in hun ateliers echte topografische elementen tot verschillende soorten landschappen die in de werkelijkheid niet bestonden maar die als 'typisch' Nederlands (vooral Hollands) werden beschouwd en daarom de indruk wekten dat ze realiteitsgetrouw waren (De Jongh 1971: 151-152). "Deze topografische tekenen verwezen naar de belangrijkste sferen van het sociale leven: defensie en militaire zorg (kasteel), vermaak en ontspanning (tafereel van een markt of een boerenfeest naast een kroeg), werk en handel (haven en scheepvaart) en uiteindelijk het gemeenschappelijke gebed en luisteren naar het woord van God (kerk)" (Ziemba 2005: 341).

\subsection{Nederlandse landschappen}

\subsubsection{Water en visserij}

Zoals hierboven werd vermeld, vinden we veel tegels in Krzyżowice die de zee, rivieren, vijvers, kanalen evenals boten, veerponten en schepen op het water of in een haven afbeelden (afb. 1-2).

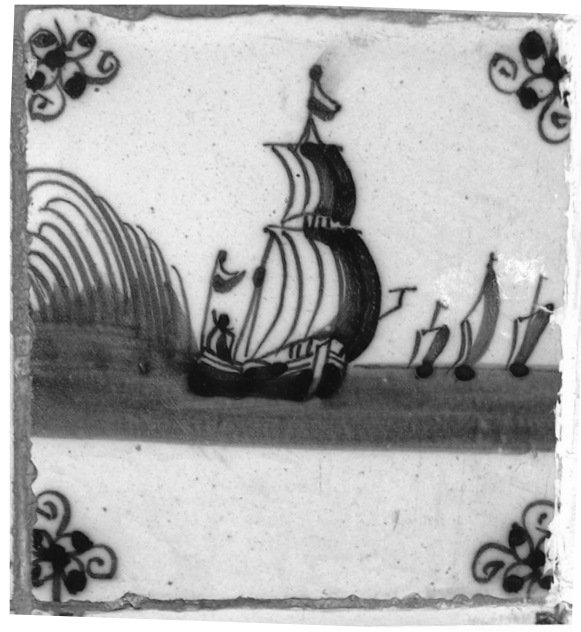

Afbeelding 1. Krzyżowice; gang: tegel met een schip; foto: Joanna Skubisz

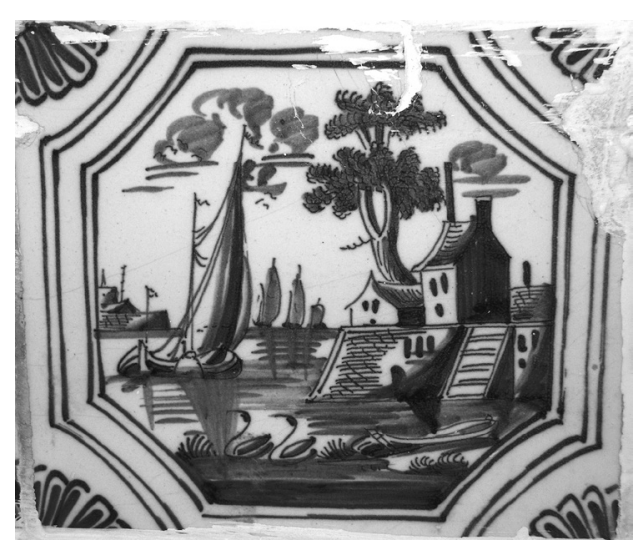

Afbeelding 2. Krzyżowice; oude eetkamer: tegel met boten; foto: Joanna Skubisz 
Deze taferelen kwamen ook meermaals voor in de Nederlandse schilderkunst en literatuur, bijv. in de emblematiek. Vaartuigen konden economische, politieke en morele kwesties symboliseren. De emblemata waren natuurlijk in de meeste gevallen geen bronnen van scènes uitgebeeld op tegels. ${ }^{9}$ Er worden alleen gelijke motieven in verschillende cultuurverschijnselen aangetroffen. Enkele voorbeelden van emblemata met boten of schepen bevinden zich bijv. in de bundel Sinnepoppen van Roemer Visscher (1614). In het embleem nr. XLIX uit het tweede deel van dit werk dat van de inscriptio De kost moet voor de baet uyt werd voorzien, toont de pictura een buis: een schip vooral bestemd voor de haringvangst (afb. 3).

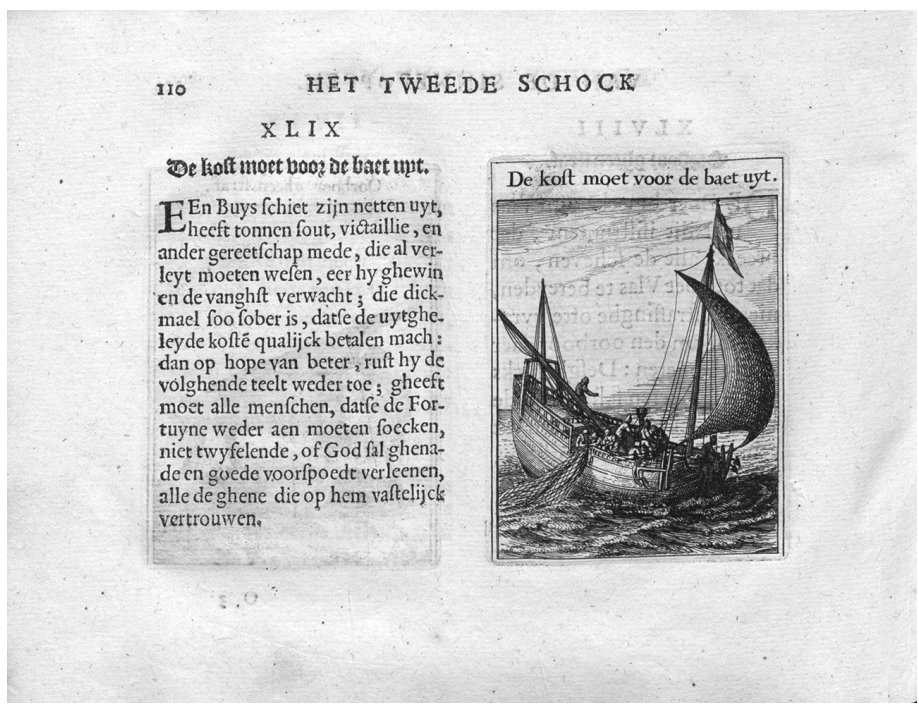

Afbeelding 3. Roemer Visscher, embleem XLIX. De kost moet voor de baet uyt. II Schock. Sinnepoppen, ed. Amsterdam 1614, BUWr OSD 019000, p. 110

In zijn commentaar dat bij het embleem hoort, betoogt de dichter dat er eerst geld moet worden geïnvesteerd om verder veel winst te kunnen behalen. Voor de haringvangst moeten vissers eerst de boot voorzien van gereedschap, voorraad en zout, wat met bepaalde kosten gepaard gaat, maar alle uitgaven worden later

9 Er zijn niet veel directe invloeden van de emblematiek op tegels vastgesteld. Echter, er worden wel enkele verbanden genoemd door Pluis en Stupperich in hun publicatie Mythologische voorstellingen op Nederlandse tegels. Sommige voorstellingen van mythische wezens op tegels tonen verbanden met picturae van J. Camerarius' Symbolorum et emblematum ex animalibus quadrupedibus desumtorum centuria altera uit 1595 of met Vorsteliicke Warande der dieren van Joost van den Vondel uit 1617. Er bestaan ook taferelen van Cupido's die kunnen worden geassocieerd met enkele emblemata uit de bundels van bijvoorbeeld D. Heinsius (Quaeris quid sit amor?, 1601) en J. Cats (Monita Amoris Virginei, 1622) (Pluis \& Stupperich 2011: 129-130, 175, 188-191). 
vergoed met de winst. Elke onderneming is riskant, maar men mag niet twijfelen aan het slagen van een opzet en de mens moet vertrouwen in God hebben (Visscher 1614: 110).

Onder de motieven van de tegels in Krzyżowice kunnen wij bovendien dieren onderscheiden die in het water of in de buurt van waterbekkens leven. Daarbij horen zeker vogels, bijv. eenden, zwanen en reigers; insecten, zoals libellen, en vissen; vermoedelijk een baars of een zeelt. Er is ook een tegel waar een mythisch wezen op wordt afgebeeld, d.i. een zeemeermin. Vanaf de zestiende eeuw tot en met de negentiende eeuw ontstonden veel prenten waarop vissen, voorzien van hun Latijnse en soms ook Nederlandse namen, werden voorgesteld. Vaak waren dat hele series van etsen en gravures, zoals de collectie Piscium Vivae Icones gepubliceerd door Claes Jansz Visscher (Amsterdam 1634) waarvoor hij ontwerpen van Adriaen Collaert, een Vlaamse ontwerper en graveur, had gebruikt. ${ }^{10}$ Dit soort prentenseries met dieren dienden soms als inspiratiebron voor de voorstellingen op tegels. Het is echter belangrijk om na te gaan of deze afbeeldingen een betrouwbare bron van kennis waren. Veel kunstenaars die dergelijke prenten maakten, hadden deze dieren nog nooit gezien, dus 'portretten' van o.m. vissen op tegels konden ook nauwelijks natuurgetrouw zijn (Oczko \& Pluis 2013: 151).

De betekenis en rol van het water in het bestaan van Nederland en in het leven van elke Nederlander was en is nog steeds van groot belang. Het verbaast dus niet dat men op de tegels in Krzyżowice het vissen (met een net of een hengel) tot de meest voorkomende activiteiten kan rekenen (afb. 4-5).

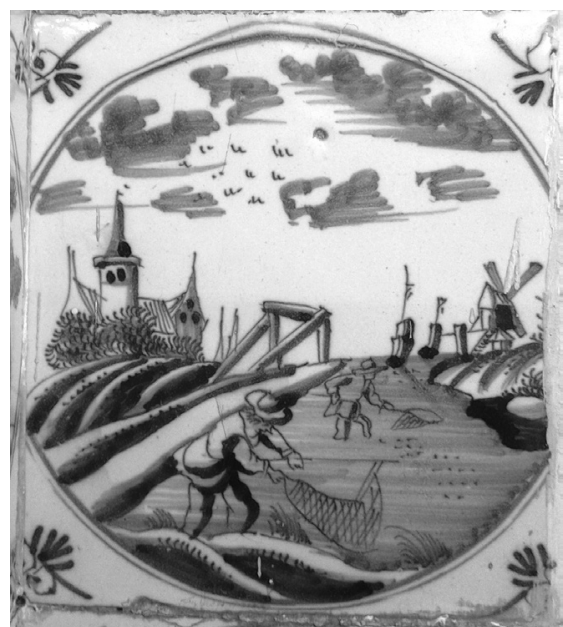

Afbeelding 4. Krzyżowice; oude eetkamer: tegel met vissers; foto: Joanna Skubisz

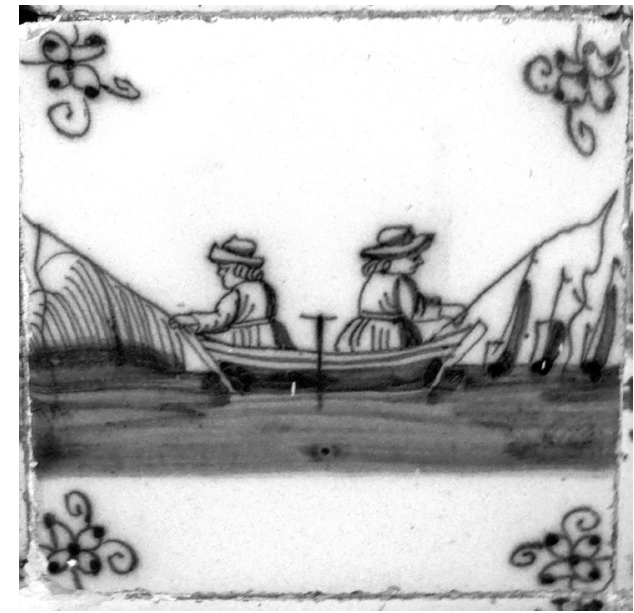

Afbeelding 5. Krzyżowice; gang: tegel met vissers; foto: Joanna Skubisz

${ }^{10}$ De eerste editie van Collaerts prentenserie verscheen in ca. 1598 in Antwerpen. De gegevens werden geraadpleegd op 16.11.2021 van: http://www.rarefishbooks.com/k2-categories/Books/304-collaert-adriaen-c-1560-1618.html. 
Naast de visserij werden hier ook andere werkzaamheden voorgesteld, bijv. het vervoer van mensen, dieren en goederen over het water.

De visserij werd in de Gouden Eeuw op grote schaal ontwikkeld en samen met de intensieve bloei van de landbouw, nijverheid en handel leidde het tot de economische welstand van het land. Het is dus niet vreemd dat het tafereel van 'vissers aan het werk' in veel cultuurverschijnselen werd gebruikt, o.m. op de tegels. De economische kwesties (bijv. van winst en verlies) speelden namelijk een belangrijke rol in het leven van toenmalige Nederlanders.

\subsubsection{Wind- en watermolens}

Wind- en watermolens waren typisch voor het Nederlandse landschap, en zijn dat in veel regio's nog altijd. Ze waren ook aanwezig op de tegels in Krzyżowice (afb. 6-7).

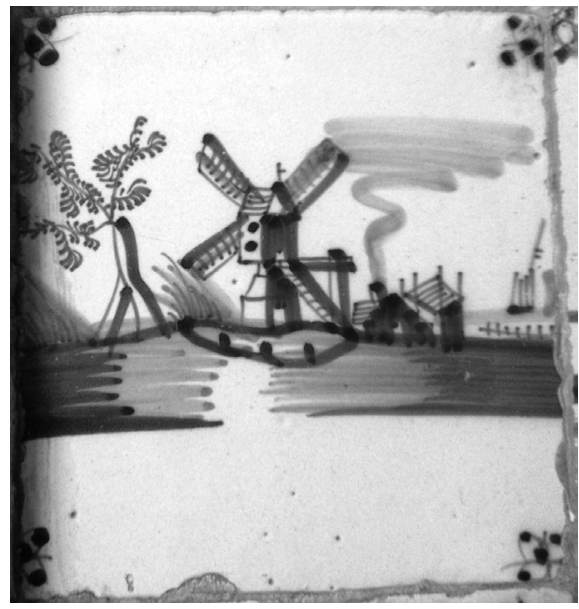

Afbeelding 6. Krzyżowice; gang: tegel met een standerdmolen; foto: Joanna Skubisz

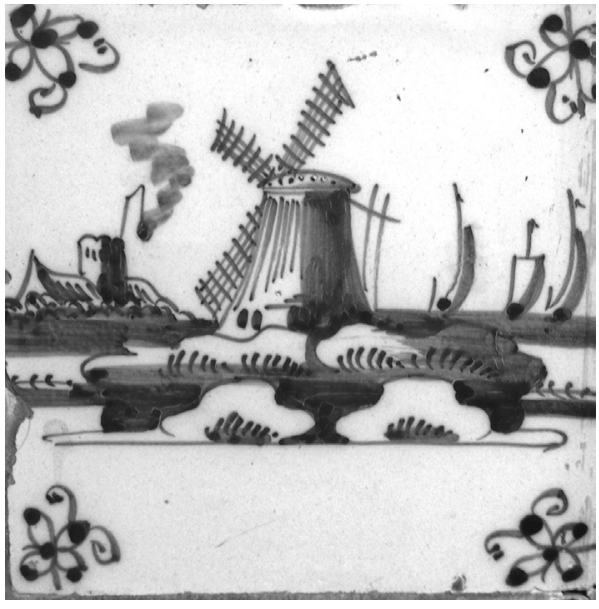

Afbeelding 7. Krzyżowice; gang: tegel met een poldermolen; foto: Joanna Skubisz

Deze gebouwen, die dankzij de natuurkrachten - wind en water - konden functioneren, vormden tevens een soort van schakel die verschillende leefruimten in de Nederlanden verbond. De rol van een molen was om van de oogst van de aarde - granen - tot meel te malen, maar zonder wind of water kon hij zijn rol niet vervullen. Daarnaast speelde de zogenaamde poldermolen een zeer belangrijke rol in het gevecht van de Nederlanders met het water. Dankzij de windkracht kan hij namelijk het water van een lager niveau naar een hoger niveau pompen en op die manier polders doen opdrogen (Oczko \& Pluis 2013: 135). De zeventiende-eeuwse kunstenaars beeldden molens op hun schilderijen uit als een element typisch voor de Nederlandse realiteit. Deze tendens is zichtbaar in verschillende 
types landschappen: het gebruik van conventionele beeldelementen is herkenbaar en begrijpelijk binnen de Nederlandse cultuur, om op deze manier het eigen publiek beter te kunnen bereiken, beschrijft o.m. Goedde (1986). Jacob Isaacksz van Ruisdael schilderde bijv. in ca. 1670 De molen bij Wijk bij Duurstede, waarin hij veel elementen gebruikte die typisch waren voor molenvoorstellingen, maar tevens voorzag hij zijn beeld van een extra aspect: hij benadrukte de rol van een molen in het leven van Nederlanders (Vels Heijn e.a. 2003: 376-377).

\subsection{Koeien}

Het beeld van het leven in de oude Nederlanden op de tegels uit Krzyżowice wordt nog verrijkt met voorstellingen van dieren: koeien en paarden. Ze horen in bepaalde mate bij de arcadische scènes die vooral vanaf het midden van de zeventiende eeuw op de tegels werden afgebeeld (Pluis \& Stupperich 2011: 192). Deze nieuwe bloei van de pastorale die in de klassieke oudheid ontstond, werd in Italië begonnen en in de zeventiende en achttiende eeuw werd het genre nagevolgd in de literatuur en kunst van andere landen, waaronder in de Nederlanden. In Nederlandse gedichten, liederen, emblemata alsmede toneelstukken werden pastorale thema's en motieven voorgesteld, waaronder de liefde van herders en herderinnen, prachtige natuur met velden, bossen, weiden, beekjes en dieren (meestal schaapjes, maar ook vee), en de verheerlijking van het leven buiten de stad (geassocieerd met de verdorvenheid) (Smits-Veldt \& Luijten 1993: 58-59). Het doel was niet om het leven en werk van de herders weer te geven, maar om hun liefdesavonturen en hun gevoelens te laten zien die weerspiegeld worden in de beschrijvingen van de natuur (Smits-Veldt \& Luijten 1993: 58-59). De droom om een 'kwade, drukke, gevaarlijke' stad te 'verruilen' voor een deugdzaam, rustig en veilig platteland kwam ook tot uiting in de schilderkunst. Er ontstonden portretten van invloedrijke stedelingen in een idyllische pastorale omgeving en bijzonder populair werden landschappen met vee, de teelt waarvan de welvaart van de staat ondersteunde (Helmers \& Janssen 2018: 4). Het resultaat van deze artistieke en literaire tendens formuleren Helmers en Janssen: "Such textual and visual images helped to create a notion of the Dutch Golden Age as a peaceful age of sociable bourgeois free living. This image was created by and for a burgher class that was responding to the new realities of city life [...], and that loved to revel in, or dream of, the innocent countryside" (4). Ten aanzien daarvan verbaast het dus niet dat we herders en herderinnen met hun dieren op tegels kunnen bewonderen, afgebeeld tegen het schilderachtige landschap van het rustige en veilige platteland. De pastorale taferelen van de tegels werden geïnspireerd door toneelstukken, zoals o.m. Il Pastor Fido van Giovanni Battista Guarini (1590) en zijn Nederlandse vertalingen: Anna Rodenburgh's Trouwen Batavier van Theo- 
dore Rodenburgh (1617) en Den Getrouwen Herder van David de Potter (1650), Granida van P.C. Hooft (1605) of Het Spaens Heydinnetje van Jacob Cats (1637) (Pluis \& Stupperich 2011: 192-196).

De bovengenoemde pastorale motieven van de tegels in Krzyżowice vergen zeker een aparte studie. Echter, in dit artikel wordt de aandacht alleen gevestigd op dieren, met name op koeien, afgebeeld op die tegels. Het is interessant dat andere diersoorten aanwezig op dit type tegels vaak een onderdeel van de achtergrond vormen waartegen herders en hun 'avonturen' worden voorgesteld. Aan de Hollandse koe daarentegen werd bijzondere aandacht geschonken. Dit dier komt bijna altijd op de voorgrond en werd herhaaldelijk getoond: staand of liggend in de wei, alleen of samen met een kudde, gemolken of poepend. Deze populariteit van de koe wekt geen verbazing als haar rol in de zuivelproductie (waar de Nederlanden beroemd om waren) onder de aandacht wordt gebracht (afb. 8-9).

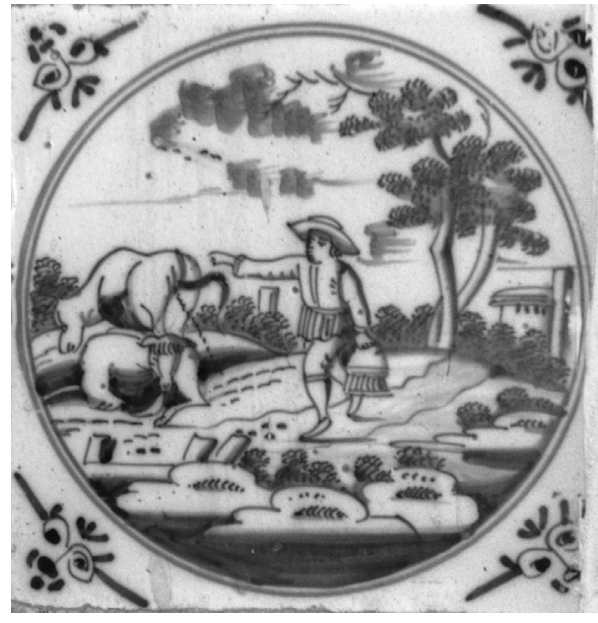

Afbeelding 8. Krzyżowice; oude eetkamer: tegels met koeien; foto: Joanna Skubisz

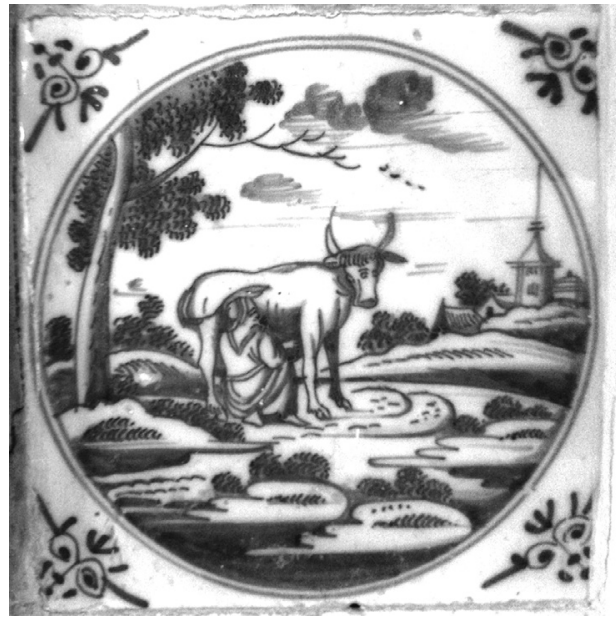

Afbeelding 9. Krzyżowice; oude eetkamer: tegel met een koe en een melkmeid; foto: Joanna Skubisz

Koeien werden vaak geportretteerd in de Nederlandse cultuuruitingen, o.m. in de kunst en poëzie. Aelbert Cuyp was een zeventiende-eeuwse kunstenaar die deze dieren meermaals schilderde en tekende. In dezelfde eeuw ontstonden ook prenten met koeien van o.m. Boëtius Adamsz. Bolswert, Herman van Swanevelt of Frederick Bloemaert. Een heel interessante prent met de titel Koeien in een landschap werd gemaakt door Hendrick Hondius in het jaar 1644. Hij stelde koeien voor in een landschap van weiden en rivieren. Onder de prent werd een onderschrift gezet: Ghy Heeren wachters wel neerstelyck toesiet, dat Ons gerooft werd de Hollandse koe niet waarmee de kunstenaar naar de toenmalige 
economische en maatschappelijke situatie in Nederland verwijst. ${ }^{11}$ Bovendien prezen de Nederlandse dichters dit dier en de producten die de inwoners dankzij de koeien konden verkrijgen. Over Nederlandse zuivelproducten schreef Jacob Cats in zijn werken Ouderdom, buyten-leven en Hof-gedachten op Sorghvliet (1655) en Tachtig-jarige bedenckingen uit $1657 .{ }^{12}$ In het tweede hoofdstuk Van Spijse en Dranck van het laatstgenoemde werk vindt de lezer het gedicht getiteld Van het gene dat van de Dieren komt. Hetzelfde gedicht werd ook geplaatst in het Nuttelyck huys-boeck uit 1769, gepubliceerd door Hendrik van der Deyster in Leiden. Dit boek bevat teksten over alles wat de mens nodig heeft om lang en gezond te kunnen leven. In deze achttiende-eeuwse editie kreeg het werk van Cats de nieuwe titel d.i. De Vruchten der Dieren en werd het ook van een gravure voorzien waarop een boerderij werd geschilderd met een boerin die een koe aan het melken is. Daarnaast beeldde de kunstenaar nog een stootkarn af waarmee men room in boter omzette. In beide versies van zijn gedicht benadrukt de auteur dat de dieren noodzakelijke producten leveren zoals melk, wei, boter en kaas, die meermaals de honger van zowel eenvoudige mensen alsook prinsen hielpen stillen. Van alle landbouwhuisdieren verkiest Cats de koe boven de andere omdat Nederland zijn heerlijke, ook in het buitenland geconsumeerde zuivelproducten aan haar te danken heeft. Dit werk lijkt op een 'lofsang' ter ere van Nederlandse koeien want "Dat stort aen alle kant uyt sijnen vollen schoot / Een dienstig onderhout, een voetsel in der noot" (Cats 1700 II: 583) en "Van daer komt nutte kost ten goede van den Mensch, / Van daer komt mont-vermaek en vollen herten wensch" (Cats 1700 II: 583). De auteur prijst daarbij inheemse producten hoger dan exotische. Hij merkt bijvoorbeeld op dat de oogst, de vruchten dus, in Spanje maar één keer per jaar worden geplukt en geëxporteerd terwijl de koe twee keer per dag haar "edel nat" schenkt en daarom biedt ze een waardevollere schat aan. De dichter richt zijn appel tot de Nederlanders om Spanje en andere landen niet te benijden, zelfs niet als ze goud en andere voortreffelijke schatten zouden bezitten. Misschien manifesteert J. Cats in deze versregels zijn negatieve mening over Spanje als politieke vijand van de Republiek. De dichter was immers een trouwe rijksambtenaar, dus zijns inziens kon deze houding van zijn toewijding aan de staat getuigen. Cats verzoekt zijn medeburgers om God dankbaar te zijn omdat Hij Zijn zegening naar hun land zendt als een regen, een Bijbels manna, en hun welzijn garandeert. Gelijke overpeinzingen presenteert deze auteur in zijn lofdicht op het landgoed Ouderdom, buyten-leven en Hof-gedachten op Sorgh-

11 De gegevens van de gravure werden geraadpleegd op 7.10.2020 van: http://hdl.handle. net/10934/RM0001.COLLECT.491844

12 Dit werk verscheen voor de eerste keer in Amsterdam in een verzameleditie van Cats' werken uit 1658. In dit artikel wordt het gebruik gemaakt van een uitgave uit 1700, gepubliceerd in Utrecht en Amsterdam, die zich in de collectie van de Universiteitsbibliotheek van Wrocław bevindt (BUWr., cat.-nr. 505816). 
vliet. De dichter zegt heel nadrukkelijk hoe gelukkig de vrije Nederlanden zijn dankzij Gods zegening:

Maer wy, $[\ldots]$ en hebben niet te klagen,

Noch van dat ons het vee, noch dat de boomen dragen,

Gebreeckt ons soet'er lucht of heet'er Sonne-schijn.

Wy hebben vry genoegh om wel te mogen zijn.

Danckt vry den grooten Godt, O vrye Nederlanden!

Van sijn gestreckte gunst, en uwe rijcke stranden; (Cats 1655: 53)

Naast Cats waren er ook andere dichters die het nut van een koe voor de Nederlandse samenleving benadrukten. Dit aspect komt ook voor in de achttiende-eeuwse poëzie, bijv. in het hofdicht Op Duynrel, Buyten-huys van de Heer van Elleméét. Onder Wassenaer (1714) van Coenraed Droste (De Vries 1985: 111). Net zoals Cats vertelt Droste erin dat dit dier twee keer per dag haar 'product', melk, levert, maar daarbij accentueert hij expliciet de betekenis daarvan voor de economische groei en de welvaart van het land. Van melk maken Nederlanders namelijk kaas en boter die worden geëxporteerd en daardoor behalen kooplieden en de staat winst (Droste 1714: 6; De Vries 1985: 111).

\subsection{Paarden, ruiters en voermannen}

In geval van de collectie in Krzyżowice kan men drie types beelden met paarden onderscheiden. Ten eerste worden deze dieren staand of liggend in het landschap afgebeeld. De tweede groep vormen taferelen van wagens of koetsen die door paarden worden getrokken en door voermannen worden gestuurd (afb. 10). Ten slotte is ook een tafereel van een ruiter op een paar tegels aanwezig (afb. 11). Ruiters werden vaak getoond op de Nederlandse tegels, wat te maken had met de toenmalige politieke situatie. De staat was verwikkeld in militaire conflicten, zoals de Tachtigjarige Oorlog (1568-1648) of de oorlogen met Engeland (vier oorlogen in de periode tussen 1652 en 1784) en Frankrijk (o.m. 1672-1679, 1688-1697, 1792-1797) (Oczko \& Pluis 2013: 141). De bewoners waren gewend aan de aanwezigheid van de soldaten: ze behoorden namelijk tot de toenmalige werkelijkheid en de vervaardigers van de tegels beschouwden hen als relevant onderwerp van hun tegels (Oczko \& Pluis 2013: 141). De man op de tegel in Krzyżowice lijkt echter niet op een soldaat; hij heeft geen wapen en harnas. Het kan een gewone man zijn die ergens te paard naartoe gaat. 


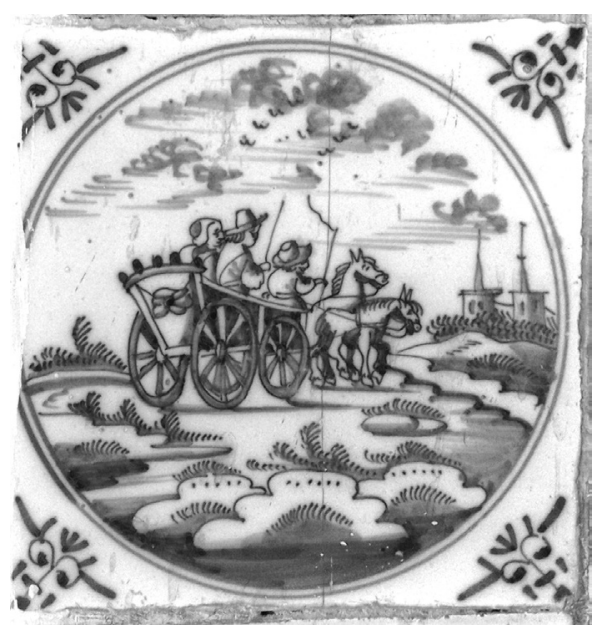

Afbeelding 10. Krzyżowice; oude eetkamer: tegel met een wagen en paarden; foto: Joanna Skubisz

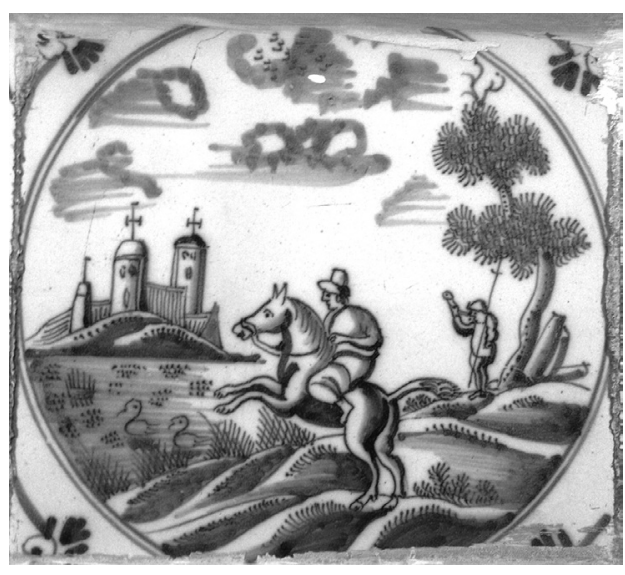

Afbeelding 11. Krzyżowice; oude eetkamer: tegel met een ruiter; foto: Joanna Skubisz

\subsection{Vermaak}

Op de tegels van Krzyżowice zijn ook scènes van ontspanning afgebeeld. Daartoe behoort het colfspel (de voorloper van het tegenwoordige golf) dat tussen de twaalfde en de dertiende eeuw is ontstaan. Mensen speelden buiten op velden, pleinen etc. Elke speler had een stok waarmee hij een bal naar een doel moest slaan. De bedoeling was om dat met zo weinig mogelijk slagen te doen. Er is ook een speciale wintervariant ontstaan: dan speelde men op het ijs. Met behulp van een stok moesten spelers een bal slaan om ermee een houten paaltje te raken. De eerste voorstellingen van het colfspel dateren uit het begin van de zestiende eeuw (Van Hengel e.a. 1982: 19). Verschillende kunstenaars, waaronder Hendrick Avercamp, Ludolf Bakhuizen, Jan Abrahams van Beestraten, Gerard ter Borch, Abraham Bloemaert, Allaert van Everdingen e.a., beeldden op hun schilderijen, prenten en etsen mensen af die aan het spelen waren. Dit thema werd ook op de tegels voorgesteld, vooral vanaf de zeventiende tot en met de negentiende eeuw (Van Hengel e.a. 1982: 54). Ze toonden beide varianten van het spel: op het land en op het ijs. Voorbeelden van deze tegels bevinden zich in de collectie van Krzyżowice. Daarop zien we vaak twee mannen die colf spelen, en van wie de eerste klaar is om te slaan en de tweede op zijn beurt wacht. Bovendien zijn er ook taferelen van een groep mensen bezig met deze sport in de wintertijd (afb. 12). Het beeld van het colfspel komt verder voor in de achttiende-eeuwse emblematabundel van Jan Luyken Des menschen begin, midden en einde (Amsterdam 1712). 


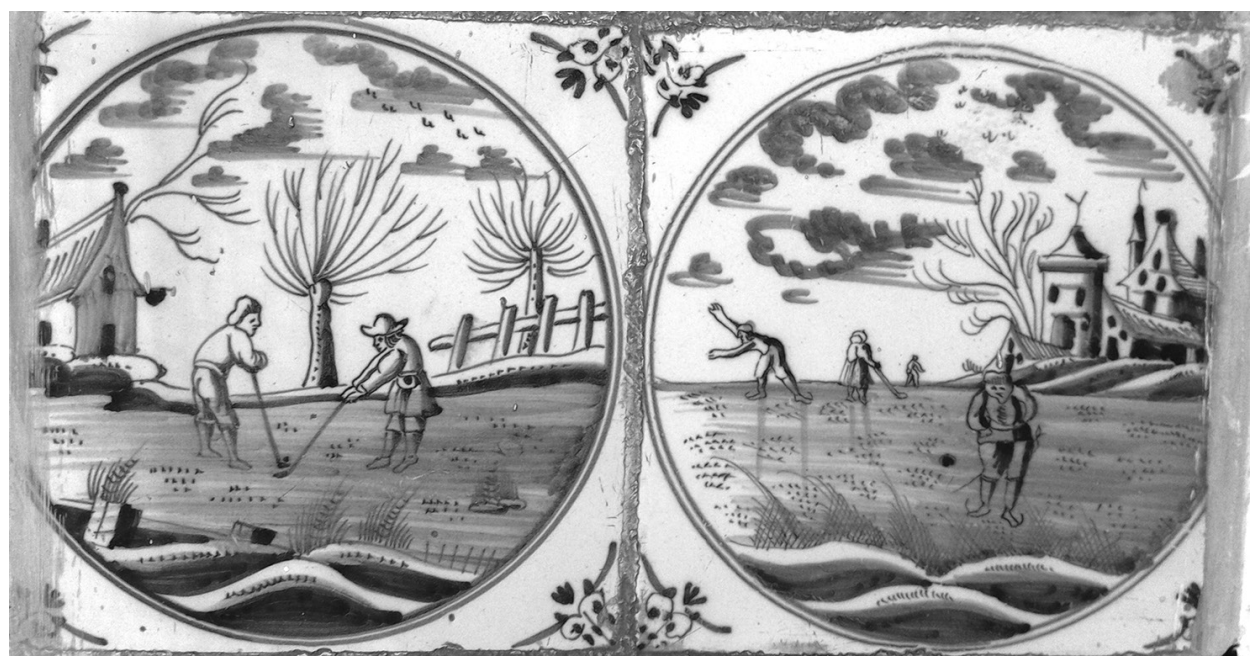

Afbeelding 12. Krzyżowice; oude eetkamer: twee tegels met het colfspel; foto: Joanna Skubisz

Op de tegels in Krzyżowice staan ook volwassenen en kinderen afgebeeld die op bevroren kanalen en vijvers schaatsen. Deze thematiek was populair in de Noord- en Zuid-Nederlandse kunst: al in de zestiende eeuw en ook later stelden de kunstenaars het ijsvermaak voor. Dit soort taferelen kunnen niet verbazen gezien het feit dat er toen 'een kleine ijstijd' was in het zeventiende-eeuwse Europa. Ook in de literatuur kwam het beeld van het schaatsen en het colfspel voor. In het Lof Van 't Landt-leven, aen Martijn Snouckaert van Schauwenburgh schrijft Johan van Heemskerck (1622):

So bind hy met een stout bestaen

Zijn vlugge schaetsen kunstigh aen,

En schijnt de lucht in 't ryen

Met vleugels te door-snyen.

Of soo 't hem lust, den bal hy slaet

En met zijn maets uyt kolven gaet,

Elck trachtend' in 't genaecken

Het paeltjen eerst te raecken:

Dus spelen zy vast in 't gelagh

Tot dat verloopen is den dagh, '...' (308).

\subsection{Religie}

Onder de verschillende soorten van Nederlandse tegels kunnen we ook de bijbeltegels onderscheiden, die verhalen uit het Oude en Nieuwe Testament weergeven. Ze bewijzen de gedetailleerde kennis van de Bijbel en getuigen van de belang- 
rijke rol van de godsdienst in het leven van de oude Nederlanders (Van Deursen 2010: 294-308, 342-355). De voorliefde voor bijbelse taferelen ontwikkelde zich vanaf de tweede helft van de zeventiende tot en met het einde van de negentiende eeuw. Aanvankelijk verwees het ontwerp van de bijbeltegels naar de protestantse godsdienst, maar vanaf het midden van de negentiende eeuw verschenen er ook motieven die overeenkwamen met de katholieke esthetiek (Oczko 2015: 69-70). Ze kwamen bijzonder vaak voor in de huizen van doopsgezinden, maar werden ook gekocht door andere gelovigen (Oczko 2015: 72). Voor vrome mensen waren ze namelijk vaak de manier om eigen geloof te versterken: een soort van brug tussen de woorden van de Bijbel en hun vroomheid. Dit type tegels vindt men ook in de collectie van Pakoszów of Wrocław (Szmida-Półbratek 2010: 18). Echter, in Krzyżowice zijn slechts enkele voorbeelden van de bijbelse tegels bewaard, bijv. met Mozes en de Tien Geboden. Misschien werden er niet veel bijbeltegels voor Krzyżowice vervaardigd of werden ze in de loop van de tijd beschadigd of vernietigd, of raakten ze verloren.

\section{Conclusie}

Het tafereel van het dagelijks leven in de oude Nederlanden weergegeven op de tegels uit de collectie van Krzyżowice sluit duidelijk aan bij het beeld van het idyllische platteland ook aanwezig in de Nederlandse literatuur en beeldende kunst. In deze wereld hoeven mensen zich geen zorgen te maken over naderende bedreigingen, maar ze moeten zich er toch van bewust zijn. Er bestaan geen moeilijkheden, gevaren of oorlogen. De sfeer is veilig: mensen kunnen hier rustig werken maar ook van het prachtige weer genieten. Watergebieden, weiden en velden worden met elkaar verbonden door het werk van de mens. De inwoners en het hele land kunnen van de resultaten van hun werkzaamheden profiteren: ze genieten van het welzijn. In dit opzicht verwijzen tegeltaferelen naar de zeventiende- en achttiende-eeuwse hofdichten of gedichten over het boerenleven.

Het Nederlandse platteland voorgesteld op de tegels in oude paleizen in Neder-Silezië heeft dus veel te bieden aan hun inwoners: prachtige natuur met planten en dieren, zuiver water, verse producten heerlijk van smaak. Men vindt hier geen spoor van bedreiging of angst, hoewel de Nederlanders goed wisten dat de natuur kwaadaardig en gevaarlijk kon zijn. Deze visie, gecreëerd met stereotiepe voorstellingen van de leefwijze in de oude Nederlanden, kwam overeen met de behoeftes van rijke graven (en in het geval van andere tegelcollecties ook met die van burgers) in Silezië in de periode van de achttiende en de negentiende eeuw. Ze bestelden in deze tijd collecties Nederlandse tegels en lieten er hun paleizen en residenties mee versieren om op die manier hun huizen letterlijk van licht te voorzien, maar er tevens glans aan te geven en hun materiële status te benadruk- 
ken. Het land afgebeeld op de tegels liet de sfeer van vrede, rust en veiligheid naar de oude Silezische paleizen verplaatsen, hoewel de realiteit op het Nederlandse platteland niet zo zorgeloos was. Met behulp van werkelijke elementen (watergebieden, boten, molens, koeien, schaatsen, colfspel etc.) werd er een beeld van het land gecreëerd dat misschien soms te idyllisch was, maar dat toch in vele opzichten en aspecten echt zou kunnen bestaan. De eigenaars van residenties in Silezië konden op die wijze samen met hun families figuurlijk van 'de vruchten van het Nederlandse dorp' genieten.

\section{Bibliografie}

Cats, Jacob (1655): Ouderdom, buyten-leven en Hof-gedachten op Sorghvliet. [Amsterdam]: J.J. Schipper. BUWr OSD 317398.

Cats, Jacob (1700): "Tachtig-jarige bedenckingen". In: Alle de wercken soo oude als nieuwe (Vol. 2). Amsterdam, Utrecht: Daniel Van Den Dalen, François Halma, De Wed. Van A. Van Someren, J. en Wilhelm Vande Water. BUWr OSD 505816.

Deursen, A.Th. van (2010): De Gouden Eeuw volgens A.Th. van Deursen. Mensen van klein vermogen. Een dorp in de polder. Maurits van Nassau, 1657-1625. Amsterdam: Uitgeverij Bert Bakker.

Droste, Coenraed (1714): “Op Duynrel, Buyten-huys van de Heer van Elleméét. Onder Wassenaer". In: De Haagse Schouburg gestoffeert (Vol. 2). 's Gravenhage: Gerrit Rammazeyn.

Gajda, Elżbieta (2007): Powiatowy Zespót Szkót Nr 1 w Krzyżowicach. 60 lat istnienia 19472007. Krzyżowice: Agencja Wydawniczo-Reklamowa Antex.

Gelderblom, Arie Jan (red.) (1994): 'k Wil rijmen wat ik bouw. Twee eeuwen topografische poëzie. Amsterdam: Em. Querido's Uitgeverij.

Goedde, Lawrence O. (1986): "Convention, Realism, and the Interpretation of Dutch and Flemish Tempest Painting”. In: Simiolus: Netherlands Quarterly for the History of Art 16: 2/3, 139-149.

Heemskerck, Johan van (1622): Pvb. Ovidii Nasonis minne-kunst, gepast op d'Amsterdamsche vryagien: met noch andere minne-dichten ende mengel-dichten, alle nieu ende te voren niet gesien. Amsterdam: Dirck Pietersz. Voskuyl, geraadpleegd op 10.01.2021 DBNL < https:// www.dbnl.org/tekst/heem001pubo01_01/heem001pubo01_01_0028.php>.

Helmers, Helmer J. / Geert H. Janssen (2018): "Introduction: Understanding the Dutch Golden Age". In: Helmers, Helmer J. / Geert H. Janssen (red.), The Cambridge Companion to the Dutch Golden Age. Cambridge University Press, 1-12.

Hengel, S.J.H. van, e.a. (1982): Colf. Kolf. Golf. Van middeleeuws volksspel tot moderne sport. Tentoonstellingscatalogus voor Museum Het Markiezenhof (Bergen op Zoom), Centrum voor Kunst en Cultuur Sint Pietersabdij (Gent), Volkskundemuseum (Antwerpen) en Museum Flehite (Amersfoort). Zutphen: Uitgeverij Terra.

Hondius, Hendrick (I) (1644): Koeien in een landschap, geraadpleegd op 7.10.2020 Rijksmuseum Amsterdam <http://hdl.handle.net/10934/RM0001.COLLECT.491844>.

Jongh E. de (1971): "Realisme en schijnrealisme in de Hollandse schilderkunst van de zeventiende eeuw". In: Van Thiel, Pieter J.J., e.a. (red.), Rembrandt en zijn tijd. Brussel: La Connaissance, 143-194.

Korf, Dingeman (1979): Tegels. Haarlem: De Haan.

Neerlandica Wratislaviensia 30, 2020

(C) for this edition by CNS 
Kuiper, Yme (2015): “Onderzoek naar de buitenplaats in de Gouden Eeuw. Een vogelvluchtperspectief”. In: Kuiper, Yme / Ben Olde Meierink (red.), Buitenplaatsen in de Gouden Eeuw. De rijkdom van het buitenleven in de Republiek. Hilversum: Verloren, 10-41.

Oczko, Piotr (2013): Miotta i krzyż. Kultura sprzatania w dawnej Holandii, albo historia pewnej obsesji. Kraków: Collegium Columbinum.

Oczko, Piotr (2015): "The Scripture on Tiles: Dutch Tiles as an Example of the Biblical Culture of Everyday in the Republic". In: Werkwinkel 10:2, 67-88.

Oczko, Piotr / Jan Pluis (2013): Gabinet farfurowy w Pałacu w Wilanowie. Studium historycznoikonograficzne. Warszawa: Muzeum Pałacu Króla Jana III w Wilanowie.

Oczko, Piotr / Jan Pluis (samenwerking) (2018): Holenderskie flizy na dawnych ziemiach polskich i ościennych. 2. Mody i wnętrza. Malbork: Muzeum Zamkowe w Malborku.

Pluis, Jan (2013): De Nederlandse tegel. Decors en benamingen. The Dutch Tile. Designs and Names 1570-1930. Leiden: Primavera Pers.

Pluis, Jan / Reinhard Stupperich (2011): Mythologische voorstellingen op Nederlandse tegels. Matamorphosen van Ovidius. Herders. Cupido's. Zeewezens. Leiden: Primavera Pers.

Perzyński, Marek (2012): Dolnoślaskie zamki, dwory i pałace. Przewodnik dla dociekliwych. Wrocław: Wrocławski Dom Wydawniczy.

Roemer Visscher (1614): Sinnepoppen. Amsterdam: Willem Jansz. Blaeu. BUWr OSD 019000.

Sluijter, Eric. J. (1990): "Hoe realistisch is de Noordnederlandse schilderkunst van de zeventiende eeuw? De problemen van een vraagstelling”. Leidschrift 6, 5-39.

Smits-Veldt, Mieke B. / Hans Luijten (1993): "Nederlandse pastorale poëzie in de 17de eeuw. Verliefde en wijze herders:”. In: Peter van den Brink, Het gedroomde land: pastorale schilderkunst in de Gouden Eeuw. Zwolle: Waanders, 58-75.

Szmida-Półbratek, Magdalena (2010): Świat zaklęty w błękicie. Pokój Beyersdorfów w Pałacu Królewskim we Wrocławiu. Die in azur verzauberte Welt. Beyersdorf-zimmer im Königsschloss in Breslau. Wrocław: Muzeum Miejskie Wrocławia.

Vels Hein, Annemarie, e.a. (2003): Verborgen verhalen. Betekenissen van Vlaamse \& Nederlandse schilderijen 15de-18de eeuw. Amsterdam: Ludion.

Vries, Willemien B. de (1985): "Toetsing van een genre: vier onbekende achttiende-eeuwse hofdichten”. De Nieuwe Taalgids 78, 110-126.

Vries, Willemien B. de (1998): Wandeling en verhandeling. De ontwikkeling van het Nederlandse hofdicht in de zeventiende eeuw (1613-1710). Hilversum: Verloren.

Wrzesiński, Wojciech (red.) (2009): Dolny Ślask. Monografia historyczna. Wrocław: Wydawnictwo Uniwersytetu Wrocławskiego.

Ziemba, Antoni (2005): Iluzja a realizm. Gra z widzem w sztuce holenderskiej 1580-1660. Warszawa: Wydawnictwo Uniwersytetu Warszawskiego. 